\title{
FUS/ERG Fusion Gene
}

National Cancer Institute

\section{Source}

National Cancer Institute. FUS/ERG Fusion Gene. NCI Thesaurus. Code C99281.

A fusion gene that results from a chromosomal translocation $t(16 ; 21)(p 11 ; q 22)$ which fuses the FUS gene with the ERG gene. This rearrangement is associated with acute myeloid leukemia. 